\title{
Nasalance Changes after Endoscopic Sinus Surgery in Patients with Chronic Rhinosinusitis
}

\author{
Ki-Sang Rha, Jun Xu, Ji-Su Park, Sung Jae Park, Youngae Kang, and Yong Min Kim \\ Department of Otorhinolaryngology, School of Medicine, Chungnam National University, Daejeon, Korea
}

\section{만성 비부비동염 환자에서 부비동 내시경수술 후 비음도의 변화}

나기상 · 허 준 · 박지수 · 박성제 · 강영애 · 김용민

충남대학교 의학전문대학원 이비인후과학교실

Received August 24, 2016

Revised October 10, 2016

Accepted November 4, 2016

Address for correspondence

Ki-Sang Rha, MD, PhD

Department of Otorhinolaryngology,

School of Medicine,

Chungnam National University,

282 Munhwa-ro, Jung-gu,

Daejeon 35015, Korea

Tel $+82-42-280-7698$

Fax $+82-42-253-4059$

E-mail ksrha@cnu.ac.kr
Background and Objectives The purpose of this study was to examine the effect of endoscopic sinus surgery (ESS) on nasalance in patients with chronic rhinosinusitis (CRS).

Subjects and Method Eighty-one CRS patients were enrolled. The nasalance scores for oral, oro-nasal, and nasal passages were measured by nasometry and the nasal cavity volume was measured by acoustic rhinometry before and at 1 and 3 months after ESS. We divided the patients into four groups according to the following surgical interventions employed: unilateral anterior ethmoidectomy (group I), bilateral anterior ethmoidectomy (group II), bilateral total ethmoidectomy (group III), and bilateral pansinus surgery (group IV). We also divided the patients into three groups according to the CT scoring system and polyp grading system.

Results In group III and IV, the nasalance scores for all passages and nasal cavity volume were significantly increased after ESS but did not return to its preoperative level at 3 months after surgery. However, there were no significant changes in nasalance scores or in the nasal cavity volume in group I. Similarly, there were no significant changes in nasalance scores in the mild group (CT scoring system) or no polyp group, whereas the nasalance scores were significantly increased postoperatively in the moderate to severe groups (CT scoring system), and in groups that have nasal polyp group.

Conclusion The nasalance scores and nasal cavity volumes were increased after ESS and remained unchanged until postoperative 3 months. Postoperative changes in nasalance scores were more remarkable in patients who had more severe disease and who underwent more extensive surgery.

Korean J Otorhinolaryngol-Head Neck Surg 2017;60(3):112-9

\section{서 론}

비강은 후각, 흡기에 대한 온도 및 습도 조절, 외부 이물질 제거 등 중요한 기능을 수행할 뿐만 아니라 음성을 변조할 수 있는 음향공명기로 생각된다. 비강을 통한 공명은 비강의 부피와 단면적, 양측 비강의 대칭성, 비점막의 음향학적 속 성 등 비강에 관계된 인자 외에도 구개인두기능(velopharyngeal function), 비강과 구강의 상대적인 저항, 언어, 발성 습 관 등 다양한 인자에 의해 영향을 받는다고 알려져 있다. ${ }^{1)}$
비강과 연결되어 있는 부비동이 음성에 미치는 역할에 대해 서는 오래전부터 논란이 있었다. ${ }^{1-3)}$ 부비동이 공명강으로서 어 느 정도 역할을 한다고 생각하는 사람이 있었던 반면 그 역할 이 미미하여 음성의 질과 연관성이 거의 없다고 보는 사람도 있었다. 이들은 구조적으로 부비동의 개구부가 작고, 개구부가 비갑개에 의해 가려져 있으며, 소리의 진동을 약화시키는 비 부비동 점막의 영향으로 인해 공명기로서 부비동의 역할이 미 미하다고 주장하였다. ${ }^{3.4}$

부비동수술 후 음성의 변화 여부에 대해서도 논란이 있지 
만 많은 의사들이 부비동수술 후 음성의 변화를 호소하는 환자들을 경험하게 된다. Havel 등는 사체를 대상으로 공명 현상을 연구한 결과 중비도 폐쇄 여부는 음향학적으로 미치 는 효과가 미미하였으나, 사골누두를 개방하여 상악동 개구 부를 노출한 경우에는 현저한 음향학적인 변화가 있었다고 하 며 부비동수술이 음성에 영향을 미칠 수 있음을 제시하였다. 따라서 정상 상태에서 부비동이 음성에 대해 미치는 영향은 미 미할지 모르지만 부비동 내시경수술은 사골동절제술 및 상 악동, 전두동, 접형동 등 부비동 자연공의 확장으로 인해 고유 비강과 부비동이 포함된 전체 비도를 통한 공명 용적의 증가 를 초래하여 수술 후 과비음(hypernasality)을 초래할 것으로 예상된다. 실제로 만성 비부비동염 환자를 대상으로 음향학적 분석 ${ }^{15-7)}$ 혹은 비음도(nasalance)를 측정한 연구 ${ }^{7-12}$ 에서도 부 비동수술이 과비음 등 음성의 질을 변화시킬 수 있다고 보고 되었다.

여러 연구에서 부비동수술 후 음성의 변화를 발표하였지만 이들의 연구 방법이 각기 다르고 대상환자 수도 많지 않았으 며, 비중격만곡이나 하비갑개 비후 등 코막힘을 초래할 수 있 는 비강 내 동반질환이 있는 환자가 그렇지 않은 환자와 섞여 있는 등 대상환자의 동질성 면에서도 문제점이 있었다. 음성의 변화는 모든 환자, 특히 직업적 음성사용자(voice prefession$\mathrm{als}$ )에게는 매우 중요한 사항이다. 따라서 수술 후 어떤 환자 에서 음성 변화가 발생할 것인가 미리 예측하는 것이 필요하 다. 그러나 이제까지 발표된 연구에서는 비용 동반 유무 및 정도, 질환의 중증도, 수술 범위 등에 따른 세분화된 분석이 이루어지지 않았다.

이러한 점을 보완하고자 본 연구에서는 수술 전 촬영한 CT score, 비용의 유무 및 정도, 그리고 수술 범위에 따라 각 각 환자군을 나누었다. 수술 전후 음향비강통기도검사를 이용 하여 전체 비강 부피를 측정하였으며 비음측정기(nasometer) 를 이용해서 비음치(nasalance score)를 측정하여 각각의 관 점에 따라 분류한 환자군 사이에 수술 전 측정치에 차이가 있 는지 그리고 수술 후 어떤 변화를 보이는지에 대하여 분석하 였다. 또한 수술 후 비음도의 변화가 비강 부피의 변화와 어떠 한 연관성이 있는지 알아 보고자 두 매개변수 사이의 상관관 계 분석을 시행하였다.

\section{대상 및 방법}

\section{대 상}

2014년 6월부터 2015년 7월까지 일측 혹은 양측 만성 비부 비동염으로 진단하고 수술을 시행한 환자 152명을 대상으로 연구를 시작하였다. 이 연구는 본 병원의 임상연구심의위원회
의 승인(IRB No. 2015-05-040)하에 전향적으로 이루어졌으 며 연구에 동의한 환자만을 연구 대상에 포함하였다. 만성 비 부비동염의 진단은 병력, 비내시경검사 및 부비동 전산화단층 촬영(CT)을 통해 이루어졌다. 환자는 만 17세 이상으로 대전. 충청권에 거주하는 사람으로 비강 및 부비동수술의 과거력, 후두 질환, 구개 장애, 음성 장애, 청력 장애, 알레르기 비염, 기관지 천식, 코막힘을 유발할 정도로 심한 비중격만곡이나 비갑개 비후가 있는 환자는 연구 대상에서 제외하였으며, 수 술 접근을 위해 비중격교정술이나 비갑개수술 등이 필요하 였던 환자도 역시 제외하였다.

환자는 수술 전 촬영한 $\mathrm{CT}$ 를 이용하여 비부비동염의 중 증도를 평가하였으며 비내시경검사로 비용의 유무 및 정도에 대한 평가를 시행하였다. 또한 비음측정기를 이용하여 비음 치를 측정하였으며, 음향비강통기도검사를 통해 전체 비강의 부피를 측정하였다. 비음치와 전체 비강의 부피는 수술 후 1 개월, 3 개월에 다시 측정하여 수술 전 측정치와 비교하였다.

연구에 참여하였던 환자 중 수술 후 3 개월까지 추적조사 가 되지 않은 환자, 3 개월까지 증상이 호전되지 않았거나 비 용이 재발한 환자 등을 제외하고 남은 환자는 81 명이었다. 본 연구에서는 이들을 대상으로 수술 범위, 비부비동염의 중증 도, 비용의 유무 및 정도에 따라 각각 환자군을 나누고 각 군 사이에 수술 전 측정치에 차이가 있는지 그리고 수술 후 어떤 변화를 보이는지 분석하였다.

\section{수술 범위에 따른 환자군의 분류}

모든 환자는 비내시경을 이용한 수술을 시행하였으며 수 술 범위에 따라 다음과 같이 분류하였다. 일측 전방부 부비 동에 병변이 국한되어 있어 일측 전사골동절제술을 시행한 경 우를 I군(unilateral anterior ethmoidectomy), 양측의 전사골 동절제술을 시행한 경우를 II군(bilateral anterior ethmoidectomy), 양측 전·후사골동절제술(bilateral total ethmoidectomy)을 시행한 경우를 III군, 그리고 전두동과 접형동을 포함한 양측 전부비동근본수술을 시행한 경우를 IV군(bilateral pansinus surgery)으로 분류하였다. 모든 환자에서 환 측에 중비도 상악동개방술(middle meatal antrostomy)을 시 행하였으며 수술 시 창의 크기는 적어도 $1 \mathrm{~cm}$ 이상이 되도록 넓게 개방하였다. 중비도를 통해 상악동 내의 병변을 제거하 기 어려웠던 환자에서는 견치와천공(canine fossa puncture) 을 통해 미세흡입절삭기(microdebrider)를 삽입하여 병변을 제거하였다.

\section{비부비동염의 중증도 및 비용점수에 따른 환자군의 분류}

수술 전 시행한 CT 영상으로 Lund-Mackay CT staging 
system ${ }^{13)}$ 에 따라 비부비동염의 정도를 분석하여, CT score가 8점 이하인 경우를 경도군(mild group), 9 16점인 경우를 중 등도군(moderate group), 17점 이상인 경우를 고도군(severe group)으로 분류하였다.

비용의 정도는 Vendelo Johansen 등 ${ }^{14)}$ 의 분류법을 약간 변 형하여 4단계로 구분하였다. 비용이 없는 경우 0점, 비용이 중 비도를 부분적으로 폐쇄하고 있거나 접사함요(sphenoethmoidal recess)에 국한되어 있는 경우를 1점, 비용이 중비도 를 완전히 막고 있으며 중비갑개 하단 아래로 내려와 있는 경우를 2점, 그리고 하비갑개 아래까지 내려와 비강을 대부 분 폐쇄하고 있는 경우를 3점으로 하여 양측의 점수를 합하 였다. 이 점수를 기준으로 비용이 없는 환자는 1군(no polyp group), 1 2점인 경우를 2군(mild group), 3점 이상인 경우를 3군(severe group)으로 분류하였다.

\section{음향비강통기도검사}

Acoustic rhinometry system(SRE-2000, RhinoScan 2.5; Interacoustics, Assens, Denmark)을 이용하여 비강의 부피 를 측정하였다. 검사 장비는 검사 직전 검교정(calibration)을 하였고 모든 검사는 잡음이 없는 방에서 한 명의 동일한 검사 자에 의해 시행되었다. 비점막의 변화를 초래할 수 있는 비충혈 제거제는 분무하지 않은 상태에서 검사를 시행하여 nosepiece 로부터 $7 \mathrm{~cm}$ 되는 지점까지의 비강 부피를 측정한 다음 양측 의 측정치를 합하여 전체 비강 부피(total nasal cavity volume) 를 구하였다.

\section{비음도 측정}

Nasometer II 3.4 system(model 6450; KayPentax, Lincoln Park, NJ, USA)을 이용하여 비음치를 측정하였으며, 비음치 측정을 위한 한국인 표준 음성표본으로는 Park 등 ${ }^{15,16}$ 이 고 안한 음성표본을 이용하였다(Table 1). 이 표본은 비자음(nasal consonant)을 전혀 포함하지 않는 33음절(syllable)의 구강 문장(oral passage), $32.6 \%$ 의 비자음과 그 외의 자음이 혼합 되어 있는 37음절의 구강-비강 문장(oro-nasal passage), 그리
고 자음이 모두 비자음으로 이루어져 있는 24음절의 비강 문 장(nasal passage)으로 구성되어 있다.

비충혈제거제는 분무하지 않은 상태에서 음향 분리대를 윗입술 상방에 수평이 되도록 위치하여 구강과 비강을 분리 하고 각 문장을 읽게 한 다음 구강음과 비강음의 음향에너 지를 각각 측정하여 비강음의 음향에너지를 비강음과 구강 음 음향에너지의 합으로 나눈 백분율 수치로 각 문장에 대한 비음치를 구하였다.

\section{통계분석}

통계분석을 위해 SPSS 22(version 22.0.0.0; International Business Machines, Armonk, NY, USA)와 GraphPad Prism 6(version 6.01; GraphPad Software, La Jolla, CA, USA)을 이용하였다. 각 군 사이의 연령, 비강 부피, CT score, 비용점수 및 비음치의 차이에 대한 통계적 유의성 검정을 위해 KruskalWallis test를 시행하였으며, 각 군 내에서 수술 전과 수술 후 비강 부피와 비음치의 변화에 대한 통계적 유의성 검정을 위 해서는 Friedman test를 사용하였다. 또한 수술 후 비강 부피 의 변화 정도와 비음치의 변화 정도 사이의 상관관계 분석에는 Spearman correlation coefficient를 이용하였다. 각 통계분석 결과 $p<0.05$ 인 경우를 유의성이 있는 것으로 평가하였다.

\section{결 과}

\section{수술 범위에 따라 분류한 환자군에서의 비교}

I군에 해당하는 환자는 11 명, II군 11 명, III군 27 명, IV군 32 명이었다. 각 군의 연령에 유의한 차이는 없었으며, I군을 제외하고는 모든 군에서 남성이 많았다. CT score와 비용점 수는 I군에서 가장 낮았으며, III군은 I군에 비해, IV군은 I, $\mathrm{II}$ 군에 비해 유의하게 높았다. 수술 전 전체 비강 부피는 I군 에 비해 II, III, IV군에서 유의하게 작았으나 II, III, IV군 사 이에는 유의한 차이가 없었다. 수술 전 비음치는 모든 문장 에서 I군에 비해 II, III, IV군에서 유의하게 낮았으나 II, III, IV군 사이에는 유의한 차이가 없었다(Table 2).

Table 1. Korean passages used for nasometric test

\begin{tabular}{|c|c|}
\hline Oral passage & 수희 가족이 바다에 갔다. 배도 타고 튜브도 탔다. 갑자기 비가 와서 집으로 돌아왔다. \\
\hline $\begin{array}{l}\text { Devoid of nasal consonant, } \\
33 \text { syllables }\end{array}$ & Suhi kajogi padae katt'a. pedo thago thjubido thatt'a. kapłagi piga wasə cibiro tolawatt'a \\
\hline Oro-nasal passage & 오늘은 대공원에 소풍 가는 날이다. 엄마가 김밥도 만드셨다. 과자랑 스케치북이랑 가져갔다. \\
\hline $\begin{array}{l}32.6 \% \text { nasal consonant, } \\
37 \text { syllables }\end{array}$ & 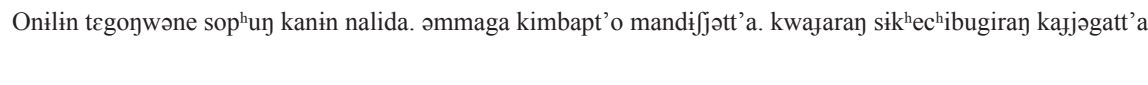 \\
\hline Nasal passage & 엄마 안녕 엄마 안녕, 매미 안녕 매미 안녕, 나무 안녕 나무 안녕 \\
\hline $\begin{array}{l}\text { Devoid of oral consonant, } \\
24 \text { syllables }\end{array}$ & Әmma annjəy əmma annjəy. memi annjəy memi annjəy. namu annjəy namu annjəy \\
\hline
\end{tabular}


Nasalance Change after Endoscopic Sinus Surgery I Rha KS, et al.

Table 2. Demographics and preoperative values of subgroups classified by the type of surgery employed

\begin{tabular}{lcccc}
\hline & Group I $(\mathrm{n}=11)$ & Group II $(\mathrm{n}=11)$ & Group III $(\mathrm{n}=27)$ & Group IV $(\mathrm{n}=32)$ \\
\hline Age & $47.09 \pm 14.54$ & $41.82 \pm 15.75$ & $44.96 \pm 12.76$ & $47.38 \pm 12.65$ \\
Sex (male/female) & $3 / 8$ & $6 / 5$ & $22 / 5$ & $21 / 11$ \\
Lund-MacKay CT score & $3.27 \pm 2.01$ & $8.82 \pm 2.44$ & $12.30 \pm 5.02^{*}$ & $14.75 \pm 5.09^{*+}$ \\
Polyp grade & $0.55 \pm 1.04$ & $0.64 \pm 0.81$ & $1.48 \pm 1.09 *$ & $2.00 \pm 0.88^{*+}$ \\
Total nasal cavity volume $\left(\mathrm{cm}^{3}\right)$ & $24.63 \pm 9.40$ & $19.58 \pm 5.82^{*}$ & $21.01 \pm 5.72^{*}$ & $19.41 \pm 5.69^{*}$ \\
Nasalance score for oral passage & $18.82 \pm 13.33$ & $14.00 \pm 6.16^{*}$ & $14.96 \pm 4.53^{*}$ & $15.34 \pm 5.22^{*}$ \\
Nasalance score for oro-nasal passage & $46.18 \pm 9.79$ & $40.36 \pm 6.89^{*}$ & $41.67 \pm 5.06^{*}$ & $40.38 \pm 7.45^{*}$ \\
Nasalance score for nasal passage & $69.18 \pm 7.00$ & $65.09 \pm 7.56^{*}$ & $65.89 \pm 5.79^{*}$ & $65.03 \pm 6.10^{*}$ \\
\hline
\end{tabular}

Data are expressed as the mean \pm standard deviation. Group I: patients underwent unilateral anterior ethmoidectomy, Group II: patients underwent bilateral anterior ethmoidectomy, Group III: patients underwent bilateral total ethmoidectomy, Group IV: patients underwent bilateral pansinus surgery. $* p<0.05$ compared with group $\mathrm{l}, t p<0.05$ compared with group II

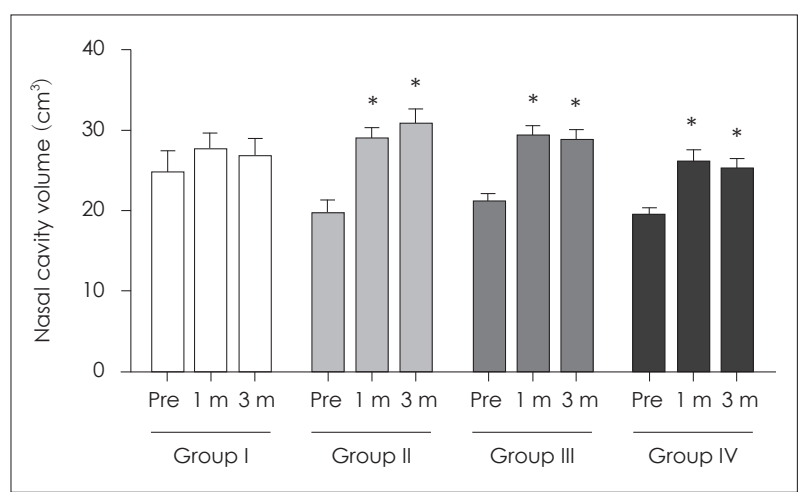

Fig. 1. Pre and postoperative values of nasal cavity volume in different groups classified by surgical interventions employed. In group II, III, and IV, the nasal cavity volume was significantly increased at 1 and 3 months after surgery. However, there are no significant changes of nasal cavity volume in group I. *indicate $p<0.05$ compared to pre value of each group. Pre: preoperative, $\mathrm{m}$ : month.

수술 후 I군에서는 전체 비강 부피의 유의한 변화를 보이지 않았으나 II, III, IV군에서는 전체 비강의 부피가 유의하게 증가하여 3개월까지도 그 상태로 유지되었다(Fig. 1). I군에서 비음치는 수술 후 모든 문장에서 유의한 변화를 보이지 않았 으며, II군에서는 일부 문장에서만 수술 후 1개월 혹은 3개월 에 유의한 변화를 보였다. 반면 III군과 IV군에서는 모든 문 장에서 수술 1 개월 후 비음치의 유의한 증가를 보였으며, 수 술 후 3개월까지도 그대로 유지되었다(Fig. 2).

\section{CT score에 의해 분류한 환자군에서의 비교}

$\mathrm{CT}$ score에 의해 분류한 결과 경도군 26 명, 중등도군 38

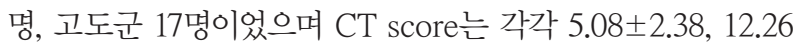
$\pm 2.40,19.94 \pm 2.16$ 으로 각 군 사이에 유의한 차이를 보였다. 또한 비용점수도 각각 $0.69 \pm 1.01,1.55 \pm 0.92,2.35 \pm 0.86$ 으 로 중등도군은 경도군에 비해, 고도군은 다른 두 군에 비해 유의하게 높았다.

수술 후 비음치를 분석한 결과 경도군에서는 모든 문장에
서 수술 후 비음치의 유의한 변화를 보이지 않았으나 중등도 군과 고도군에서는 모든 문장에서 수술 1 개월 후 비음치의 유 의한 증가를 보였으며 이는 수술 후 3개월까지도 그대로 유지 되었다(Fig. 3).

\section{비용점수에 따라 분류한 환자군에서의 비교}

비용점수에 의해 분류한 결과 1 군이 23 명, 2 군이 50 명, 3 군 이 8 명이었으며 비용점수는 각각 $0,1.78 \pm 0.42,3.50 \pm 0.53$ 으로 각 군 사이에 유의한 차이를 보였다. 또한 각 군의 CT score는 각각 $6.00 \pm 3.89,13.46 \pm 4.72,15.75 \pm 6.32$ 로 1 군에 비해 2군 과 3군에서 유의하게 높았다.

수술 후 비음치를 분석한 결과 1 군에서는 모든 문장에서 수술 후 비음치의 유의한 변화를 보이지 않았으나 2군과 3 군 에서는 모든 문장에서 수술 1 개월 후 비음치의 유의한 증가 를 보였으며 이는 수술 후 3개월까지도 그대로 유지되었다 (Fig. 4).

\section{수술 후 비음치와 비강 부피 변화의 상관관계 분석}

수술 후 비음치의 변화가 비강 부피의 변화 정도와 어느 정 도 연관성을 보이는지 알아보고자 전체 환자를 대상으로 두 매개변수 사이의 상관관계를 분석하였다. 그 결과 모든 문장 에서 수술 후 1 개월 및 3 개월에 측정된 두 변수 사이에 유의 한 상관관계를 보이지 않았다(Fig. 5).

\section{고 찰}

부비동수술은 비강 및 부비동의 구조적, 조직학적 변화뿐 만 아니라 기능적인 변화를 초래할 것으로 생각된다. Chen 등 ${ }^{17)}$ 은 일측에 부비동 내시경수술을 받은 환자의 $\mathrm{CT}$ 소견을 토대로 3차원적인 비강의 모델을 만들어 전산유체역학(comutational fluid dynamics) 시뮬레이션을 통해 양측 비강과 부비동을 통하는 기류의 기체역학적 분석을 시행한 결과 사 

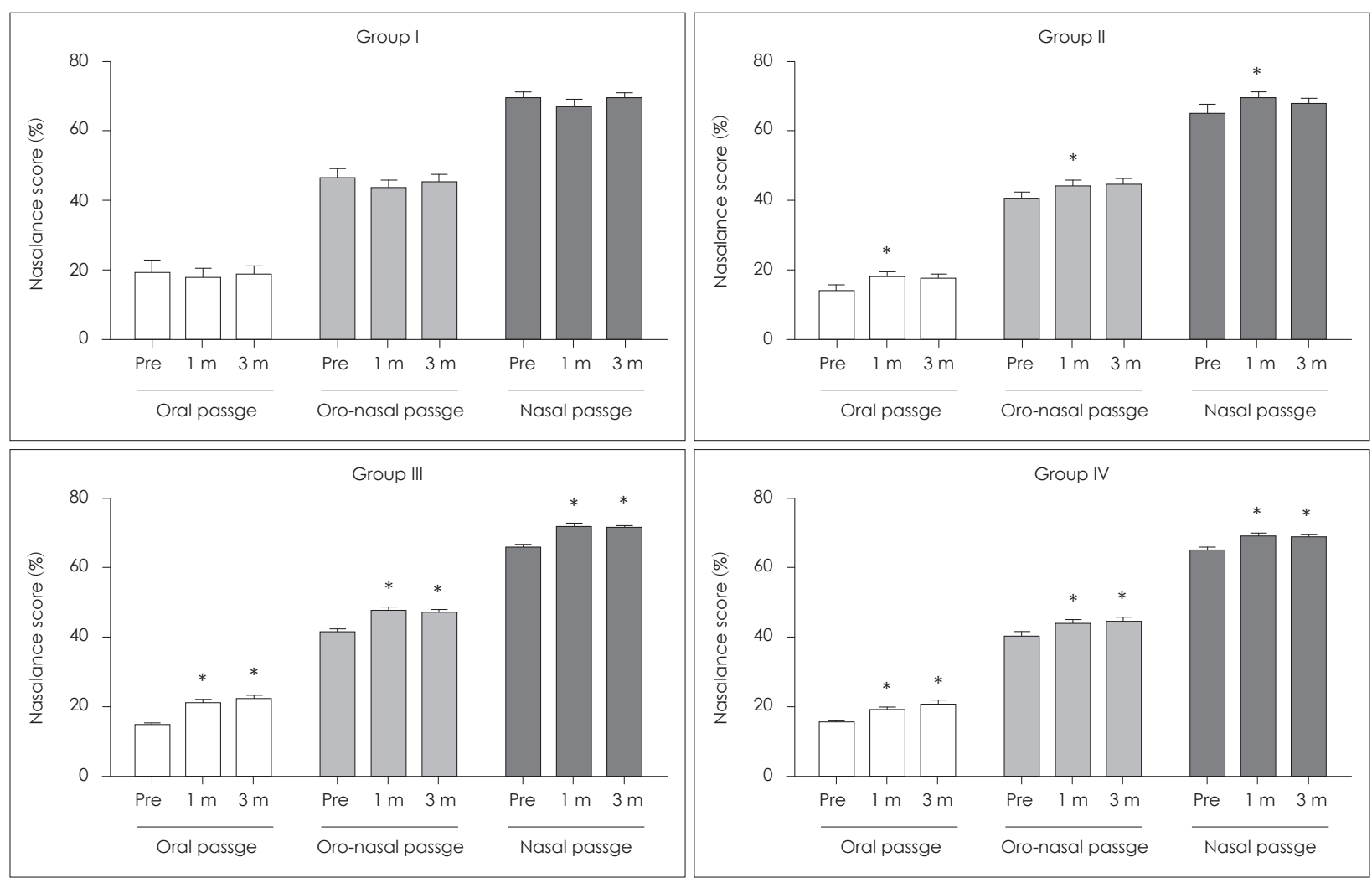

Fig. 2. Pre and postoperative values of nasalance score in different groups classified by surgical interventions employed. There are no significant changes of nasalance score in group I, whereas the nasalance scores for all passages were significantly increased after surgery in group III and IV. *indicate $p<0.05$ compared to pre value of each passage. Pre: preoperative, m: month.
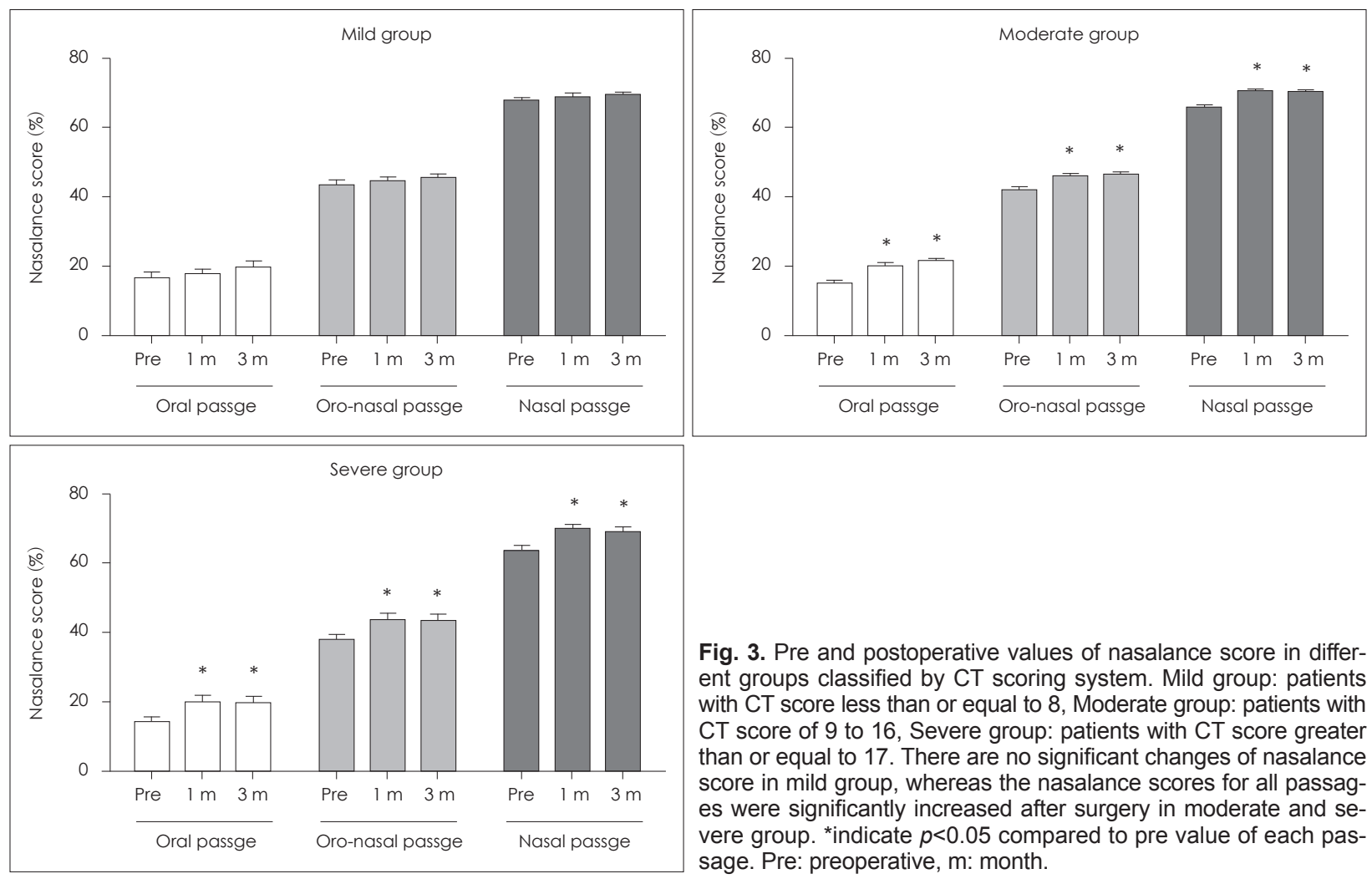

Fig. 3. Pre and postoperative values of nasalance score in different groups classified by CT scoring system. Mild group: patients with CT score less than or equal to 8, Moderate group: patients with CT score of 9 to 16, Severe group: patients with CT score greater than or equal to 17. There are no significant changes of nasalance score in mild group, whereas the nasalance scores for all passages were significantly increased after surgery in moderate and severe group. *indicate $p<0.05$ compared to pre value of each passage. Pre: preoperative, m: month. 
골동절제술과 상악동 개구부의 확장은 고유 비강과 이들 부 비동 부위의 기체역학적인 패턴의 변화를 초래하여 상악동, 사골동, 접형동 부위로 더 많은 기류가 향하게 되고 따라서
여러 측면에서 비강의 생리에 영향을 줄 것이라고 하였다.

Hosemann 등은 부비동수술이 음성에 두 가지 영향을 줄 것으로 예상된다고 하였다. 비부비동 점막의 제거는 점막에
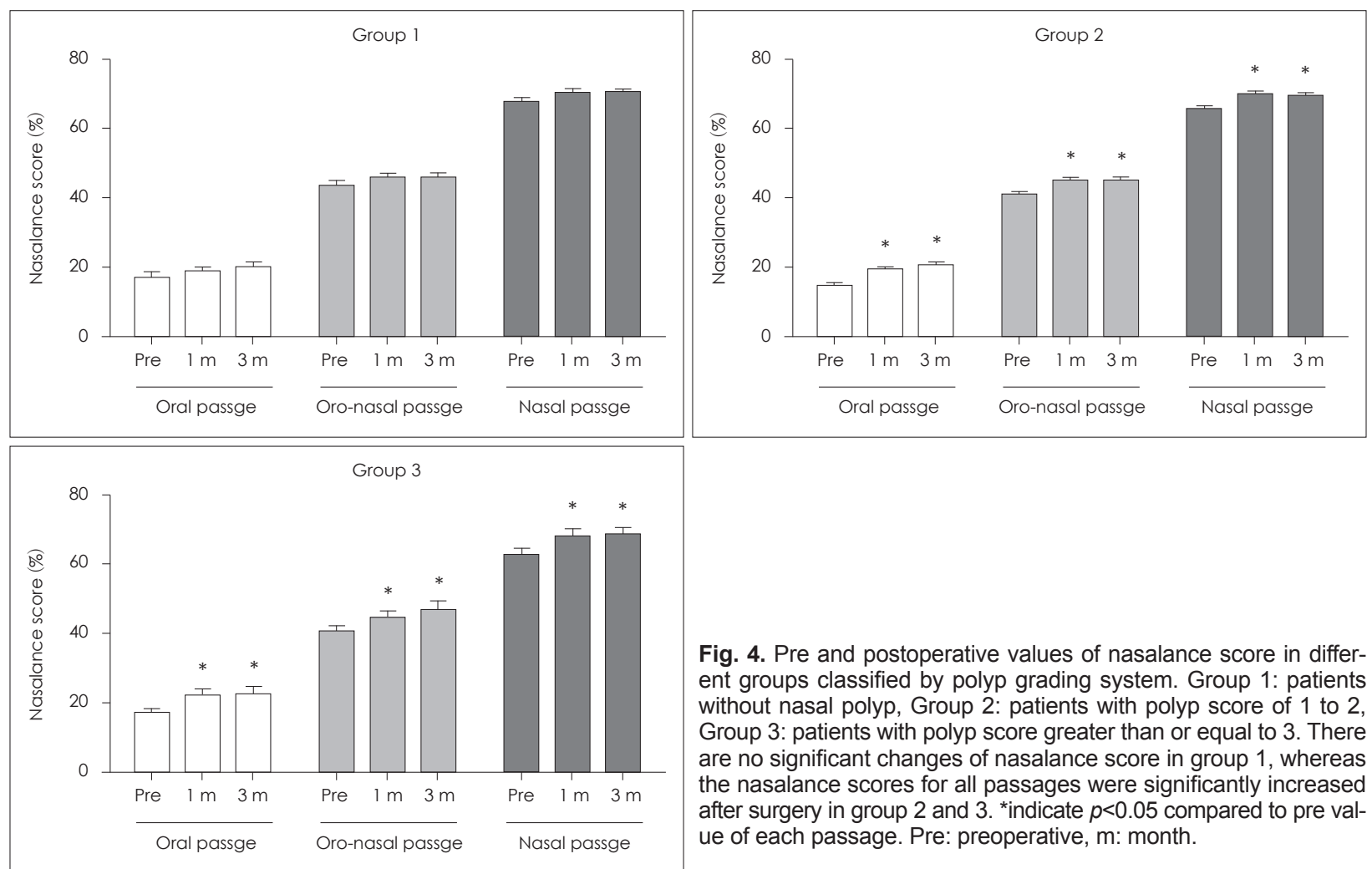

Fig. 4. Pre and postoperative values of nasalance score in different groups classified by polyp grading system. Group 1: patients without nasal polyp, Group 2: patients with polyp score of 1 to 2 , Group 3: patients with polyp score greater than or equal to 3 . There are no significant changes of nasalance score in group 1, whereas the nasalance scores for all passages were significantly increased after surgery in group 2 and 3 . *indicate $p<0.05$ compared to pre value of each passage. Pre: preoperative, m: month.

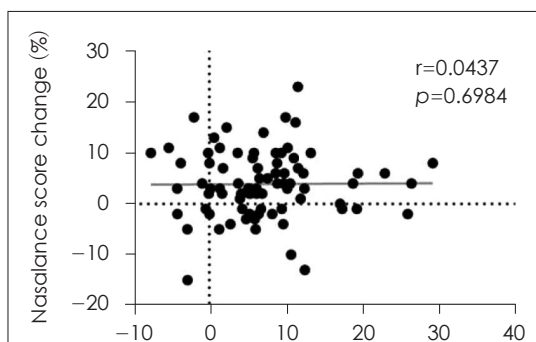

A Nasal cavity volume change $\left(\mathrm{cm}^{3}\right)$

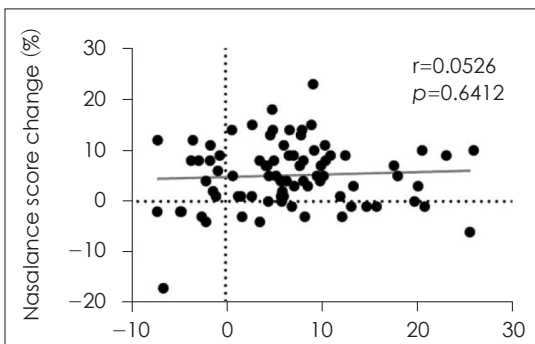

D

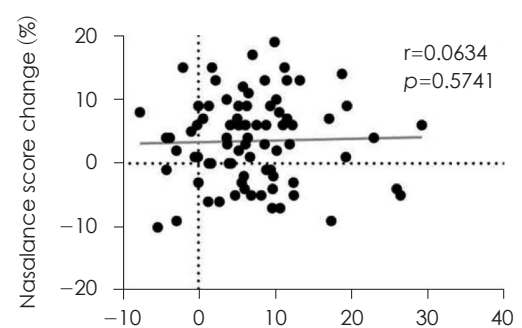

B

Nasal cavity volume change $\left(\mathrm{cm}^{3}\right)$

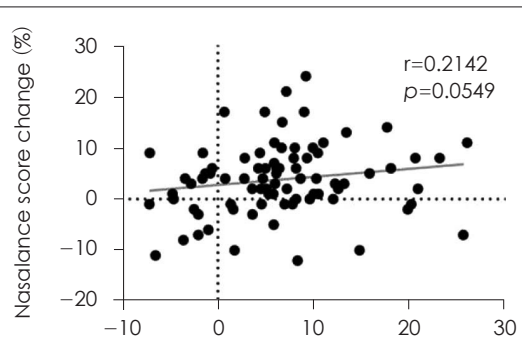

E

Nasal cavity volume change $\left(\mathrm{cm}^{3}\right)$

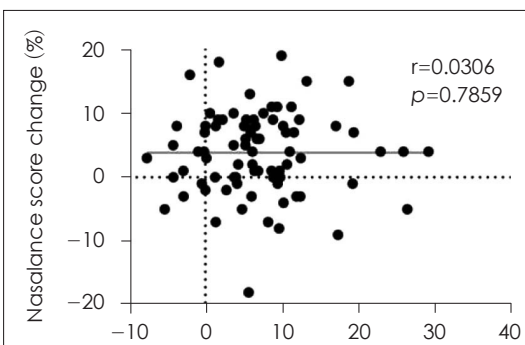

C Nasal cavity volume change $\left(\mathrm{cm}^{3}\right)$

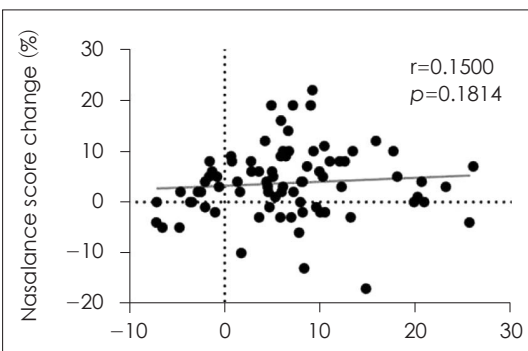

F Nasal cavity volume change $\left(\mathrm{cm}^{3}\right)$

Fig. 5. Correlation between postoperative changes in nasalance score and nasal cavity volume in total subjects. Correlations between two parameters at postoperative 1 month are represented at A (oral passage), B (oro-nasal passage), and C (nasal passage). Correlations at postoperative 3 months are represented at $D$ (oral passage), $E$ (oro-nasal passage), and $F$ (nasal passage). There were no significant correlations between changes in nasal cavity volume and nasalance for all passages at postoperative 1 and 3 months. 
의한 음향감쇠(acoustic dampening) 효과의 감소를 초래하 여 제1음형대(first formant)의 대역폭(bandwidth)과 진폭(amplitude)의 변화를 초래할 수 있으며, 수술 후 비강의 단면적 증가뿐만 아니라 상악동과 접형동이 헬름홀츠공명기(Helmholtz resonator)로 작용을 하게 되는 등 비강과 부비동 사이의 음향결합(acoustic coupling)의 증가로 인해 과공명을 초래 할 것이라고 하였다. 실제로 최근에 만성 비부비동염 환자를 대상으로 음향학적 분석 혹은 비음도를 측정한 연구에서도 부비동수술이 과비음 등 음성의 질을 변화시킬 수 있다고 보 고되었다. ${ }^{1,5-12)}$

그러나 수술 후 음성의 변화 여부 및 그 정도는 일률적이지 않고 환자 개인의 구조적인 특성, 병리학적 소견, 수술 방법 및 수술 범위 등 다양한 인자에 의해 좌우될 수 있을 것이다. 이전의 연구는 대상환자의 동질성 면에서 문제점이 있었으며 대부분의 연구에서 비용 동반 여부, 질환의 중증도, 수술 범 위 등에 따른 세분화된 분석이 이루어지지 않았다. 따라서 본 연구에서는 구조적인 변수를 줄이고자 심한 비중격만곡이나 비갑개 비후가 있는 환자는 대상에서 제외하였으며 CT score, 비용의 유무 및 정도, 그리고 수술 범위에 따라 각각 환자군 을 나누었다.

모든 환자에서 중비도 상악동개방술을 시행하였고 전·후 사골동, 전두동 및 접형동의 포함 여부에 따라 네 군으로 나 누어 분석하였다. 그 결과 수술 전 $\mathrm{CT}$ score와 비용점수는 Table 2에서 보는 바와 같이 III군은 I군에 비해, IV군은 I, II 군에 비해 유의하게 높았고, 전체 비강 부피는 I군에 비해 II, III, IV군에서 유의하게 작았다. 또한 수술 전 비음치는 모든 문장에서 I군에 비해 II, III, IV군에서 유의하게 낮았다. 이 는 예상했던 결과로 보다 광범위한 수술이 시행된 환자군이 질병의 중증도가 높고, 비용점수가 높았으며, 수술 전 비강 부 피는 더 작았고 저비음(hyponasality)을 보였음을 의미한다.

수술 후 변화를 분석한 결과 I군에서는 전체 비강 부피의 유의한 변화를 보이지 않았으나 II, III, IV군에서는 전체 비강 의 부피가 유의하게 증가하여 3개월까지도 그 상태로 유지되 었다. 비음치는 I군에서는 모든 문장에서 유의한 변화를 보 이지 않았던 반면 II군에서는 일부 문장에서만, 그리고 III, IV군에서는 모든 문장에서 수술 1 개월 후 유의한 증가를 보 였으며 이는 수술 후 3개월까지도 그대로 유지되었다. 이는 일 측 전사골동절제술과 상악동수술만으로는 비강의 부피나 비 음도에 큰 영향을 주지 않으며 양측 전·후사골동절제술 혹 은 전부비동근본수술을 시행한 경우에만 수술 후 음성 변화 가 발생할 수 있음을 의미하는 소견이다.

수술 전 CT score에 의해 부비동염의 중증도를 분류하였 을 때 Fig. 3에서 보는 바와 같이 경도군에서는 모든 문장에
서 수술 후 비음치의 유의한 변화를 보이지 않았으나 중등도 군과 고도군에서는 모든 문장에서 수술 후 비음치의 유의한 증가를 보였다. 또한 비용점수에 의해 분류하였을 때에도 Fig. 4에서 보는 바와 같이 1군에서는 모든 문장에서 수술 후 비음치의 유의한 변화를 보이지 않았으나 2군과 3군에서 는 모든 문장에서 수술 후 비음치의 유의한 증가를 보였다. 이러한 현상은 CT score와 비용점수가 수술 범위와도 연관성 이 있기 때문이라 생각한다. 실제로 수술 I군에서는 CT score 에 의한 분류에서 중등도 및 고도군에 속했던 환자가 전혀 없 었지만 II, III, IV군에서는 각각 $63.6,77.8,84.4 \%$ 를 차지하 였다. 또한 비용이 있었던 환자가 수술 I군에서는 $27.3 \%$ (3/11)로 적었지만, II, III, IV군에서는 각각 45.5, 74.1, 93.8\% 를 차지하였다. 따라서 CT score가 높고 비용을 동반하거나 다발성 비용이 있을 때 보다 광범위한 수술이 필요하고 그로 인해 수술 후 비음도가 증가할 것이라고 예측할 수 있다.

수술 후 비음도의 변화가 어떤 기전에 의한 것인지는 확실 치 않다. 그러나 공명강으로서 역할을 하는 비강의 부피 증가 가 비음도의 증가에 어느 정도 역할을 할 것으로 생각된다. 그 러나 이전에 약물처치나 수술 후 음향비강통기도검사에 의 해 측정한 비강의 부피와 비음도 사이의 상관관계를 연구한 논문은 다양한 결과를 보고하였다. Birkent 등 ${ }^{18)}$ 은 비충혈제 거제 분무 후 비음치와 비강 부피는 각각 유의하게 증가하였 으나 이 두 가지 매개변수 간의 상관관계는 유의하지 않았다 고 하였다. 또한 Jiang과 Huang ${ }^{10)}$ 은 부비동 내시경수술 후 비 음치와 비강 부피는 모두 유의하게 증가하였으나, 비음치의 증가는 비강의 일부분, 즉 중간 및 후방부의 부피 변화 사이에 서만 유의한 상관관계를 보여 비음치의 증가가 비강 부피의 증 가에 의해서만 일어나는 것은 아니라고 하였다.

본 연구에서도 비강의 부피 변화가 비음도 변화에 중요한 역할을 하는지 알아보고자 전체 환자를 대상으로 비강 부피 의 변화와 비음도 변화 사이의 상관관계를 분석하였다. 그 결과 모든 문장에서 수술 후 1 개월 및 3 개월에 측정된 두 매 개변수 사이에 유의한 상관관계를 보이지 않았다. 이러한 결 과는 수술 후 비음도의 변화는 비강의 부피 변화보다는 다 른 인자에 의한다고 해석할 수 있지만 이 같이 결론을 내리는 것은 음향비강통기도검사와 비음측정기가 가지고 있는 한계 때문에 신중을 기해야 한다고 생각한다. ${ }^{19,20)}$ 특히 음향비강통 기도검사는 비강 전방부의 단면적은 비교적 정확하게 평가 할 수 있는 반면 후방부의 단면적이나 비강 부피를 측정하는 데는 정확도가 떨어진다는 것은 이미 잘 알려진 사실이다. 또 한 검사의 특성 때문에 수술 후 넓어진 통로를 통해 비강과 연결되어 있는 부비동의 부피를 실제로는 잘 반영할 수 없을 것으로 생각한다. 
수술 후 증가되었던 비음도가 계속 유지되는지 아니면 수 술 전 수준으로 감소하는지에 대해서는 아직 잘 알려져 있지 않다. $\operatorname{Kim}$ 등 $^{11)}$ 은 수술 후 1 개월째 증가하였던 비음치가 수 술 3개월 후에 수술 전 수준으로 회복되었다고 하였으나, Dhong 등 ${ }^{8)}$ 은 3 개월에도 비음치의 유의한 증가를 보였다고 보고하였다. 또한 $\mathrm{Kim}$ 등리은 수술 후 1 개월에 비음치가 가장 높았으나 이후 서서히 감소하여 5 6개월에 수술 전 비음치로 회복된다고 하였다. 본 연구에서는 3 개월 후에도 비강의 부 피와 비음치 모두 증가된 상태로 유지되었다. 이렇게 각 연구 마다 다양한 결과를 보인 것은 술자의 수술 방법에 따른 차 이, 수술 후 비부비동 점막이 기능적으로 정상화되기까지의 기간, 치유과정에서 나타날 수 있는 반흔 조직에 의한 유착이 나 협착의 유무, 수술 후 개인의 발성 습관 변화 등 여러 인자 때문이 아닌가 생각한다. 따라서 이에 대해 보다 세분화된, 그리고 보다 장기간의 추적을 통한 연구가 필요하다고 생각 한다.

이상의 결과를 종합하면 부비동염의 중증도가 높은 경우, 그리고 비용을 동반한 경우, 양측 전·후사골동절제술 혹은 전부비동근본수술 등 광범위한 수술이 필요한 환자에게는 수술 전에 음성이 변할 가능성이 높다는 것을 확실히 주지 할 필요가 있을 것이다. 그러나 이러한 음성의 변화가 언제까 지 지속될지에 대해서는 기존의 연구보다 더 장기간에 걸친 연구가 필요할 것으로 생각한다. 수술 후 비음도와 비강 부 피 모두 유의하게 증가하여 비강 부피 변화가 비음도 변화에 중요한 역할을 할 것으로 예상하였으나 상관관계 분석에서 는 모든 문장에서 두 매개변수 사이에 유의한 상관관계를 보 이지 않았다. 따라서 비음도와 비강 부피 측정치의 정확성에 문제점이 있다는 것을 감안하더라도 수술 후 비음도의 변화 에는 비강의 부피 변화 이외의 다른 여러 인자도 관여할 것 이라 생각한다.

\section{Acknowledgments}

This work was supported by research fund of Chungnam National University, 2015.

\section{REFERENCES}

1) Hosemann W, Göde U, Dunker JE, Eysholdt U. Influence of endoscopic sinus surgery on voice quality. Eur Arch Otorhinolaryngol 1998; 255(10):499-503.
2) Masuda S. [Role of the maxillary sinus as a resonant cavity]. Nihon Jibiinkoka Gakkai Kaiho 1992;95(1):71-80.

3) Keir J. Why do we have paranasal sinuses? J Laryngol Otol 2009;123 (1):4-8.

4) Havel M, Ertl L, Bauer D, Schuster M, Stelter K, Sundberg J. Resonator properties of paranasal sinuses: preliminary results of an anatomical study. Rhinology 2014;52(2):178-82.

5) Kim CS, Kong SK, Lee HS, Cho KS, Wang SG, Roh HJ. Analysis of changes in nasal formant, spectra and resonant volume in rhinosinus after endoscopic sinus surgery. Korean J Otolaryngol-Head Neck Surg 2000;43(11):1208-15.

6) Chen MY, Metson R. Effects of sinus surgery on speech. Arch Otolaryngol Head Neck Surg 1997;123(8):845-52.

7) Hong KH, Kwon SH, Jung SS. The assessment of nasality with a nasometer and sound spectrography in patients with nasal polyposis. Otolaryngol Head Neck Surg 1997;117(4);343-8.

8) Dhong HJ, Kim SI, Kwon JK, Yun YS, Kang SM, Chu KC. Effects of endoscopic sinus surgery on nasality. Korean J Otolaryngol Head Neck Surg 1999;42(7):871-5.

9) Soneghet R, Santos RP, Behlau M, Habermann W, Friedrich G, Stammberger $\mathrm{H}$. Nasalance changes after functional endoscopic sinus surgery. J Voice 2002;16(3):392-7.

10) Jiang RS, Huang HT. Changes in nasal resonance after functional endoscopic sinus surgery. Am J Rhinol 2006;20(4):432-7.

11) Kim YH, Lee SH, Park CW, Cho JH. Nasalance change after sinonasal surgery: analysis of voice after septoturbinoplasty and endoscopic sinus surgery. Am J Rhinol Allergy 2013;27(1):67-70.

12) Kim SD, Park HJ, Kim GH, Wang SG, Roh HJ, Cho KS. Changes and recovery of voice quality after sinonasal surgery. Eur Arch Otorhinolaryngol 2015;272(10):2853-9.

13) Lund VJ, Mackay IS. Staging in rhinosinusitus. Rhinology 1993;31 (4):183-4.

14) Vendelo Johansen L, Illum $P$, Kristensen $S$, Winther $L$, Vang Petersen S, Synnerstad B. The effect of budesonide (Rhinocort) in the treatment of small and medium-sized nasal polyps. Clin Otolaryngol Allied Sci 1993;18(6):524-7.

15) Park M, Baek WS, Lee E, Koh KS, Kim BK, Baek R. Nasalance scores for normal Korean-speaking adults and children. J Plast Reconstr Aesthet Surg 2014;67(2):173-7.

16) Park SJ, Park JS, Xu J, Kang Y, Kim YM, Rha KS. Analysis of nasalance in patients with chronic rhinosinusitis. J Rhinol 2016;23 (1):31-8.

17) Chen XB, Lee HP, Chong VFH, Wang DY. Aerodynamic characteristics inside the rhino-sinonasal cavity after functional endoscopic sinus surgery. Am J Rhinol Allergy 2011;25(6):388-92.

18) Birkent H, Erol U, Ciyiltepe M, Eadie TL, Durmaz A, Tosun F. Relationship between nasal cavity volume changes and nasalance. J Laryngol Otol 2009;123(4):407-11.

19) Cankurtaran M, Celik H, Coșkun M, Hizal E, Cakmak O. Acoustic rhinometry in healthy humans: accuracy of area estimates and ability to quantify certain anatomic structures in the nasal cavity. Ann Otol Rhinol Laryngol 2007;116(12):906-16.

20) Dalston RM. Acoustic assessment of the nasal airway. Cleft Palate Craniofac J 1992;29(6):520-6. 